\title{
Theoretical analysis of microfinance on poverty alleviation
}

\author{
Prasansha Kumari \\ Department of Economics, University of Kelaniya, 11600, Sri Lanka \\ *Corresponding Author email: prasansa@kln.ac.lk
}

Submission: 20 July 2020

Revised: 24 August 2020

Accepted: 19 September 2020

\begin{abstract}
The objective of this paper is to investigate the theoretical background of microfinance and poverty alleviation. The research was followed by the integrative review method based on the available past literature related to the theoretical analysis of microfinance. Information was gathered from relevant journal papers, books, and other relevant documents. Collected information was analyzed under two categories. The study found two types of theories, which related to microfinance on the poor. The first types of theories address the specific issues the poor have to face when seeking access to formal financial resources, due to the lack of collateral. The second set of theories are based on the impact of microfinance on small businesses, households, and individuals. The first category of theories consists of theories relating to the emergence of microfinance, the concept of joint liability group in microfinance. Theories of impact pathway of microfinance consist theory on shortcomings of development finance strategies, market and welfare theories, and poverty lending approach, financial system approach, and financial integrated approach. The findings of the study are directly relevant to the policymakers and MFIs. The study's outcomes revealed that specific issues the lowincome households have to face when trying to access credits from financial institutes due to their inability to provide any collateral. This analysis provides an understanding to develop policies of MFIs to overcome those issues to reach the poor into the formal credits. The study is limited to analyses of the two categories of theories. The future researcher can focus on the theories which address the new outlook of current microfinance service
\end{abstract}

Keywords: Microfinance, Poverty Reduction, Theories, Joint Liability Group

\section{INTRODUCTION}

There are different definitions of poverty alleviation. According to the World Bank, (2019), poverty alleviation is "the strategic use of tools such as education, economic development, and health and income redistribution to improve the livelihoods of the world's poorest by governments and internationally approved organizations." Poverty alleviation is intended to permanently lift the poor out of poverty by enhancing their economic and humanitarian capacity. Poverty alleviation also helps to raise the standard of living of people who are already poor (Kumari, 2020). It has been identified as a key mechanism to reduce world poverty in the recent past. Providing access to credit for the poor is a major strategy that is employed to uplift the living standard of the poor.

People who are unable to access basic daily needs could be said to be suffering from income poverty. Alleviating poverty is achieved by increasing the income level of the poor. Microcredit service provides financial assistance to invest in income-generating activities 
and to develop small-scale businessesfor the poor, particularly those in the rural agricultural areas. The poverty of agricultural workers can be caused because of seasonal decline and disaster, brought on by bad weather conditions. Microfinance is a key tool intended to meet the financial needs of poor borrowers living in those areas (Ali \& Alemu, 2019, Kumari et al, 2019). MF can overcome such critical situations and protect their livelihoods (Johnson \& Rogaly, 1997). Recently, microfinance has been used as a key tool to empower the poor in developing countries, particularly in South Asian Countries. There is a wealth of literature on microfinance. However, the lack of literature about the theoretical background of microfinance for poverty alleviation. This paper intends to analyze the theoretical background of microfinance

The rural financial sector can be divided into two main parts as formal and informal financial activities. The formal financial sector began from around 1950 in the developing economies and was based on subsidized loans granted by government-controlled or other key institutions. There are various theoretical assumptions about the expansion of loan coverage via government intervention. Rural micro-entrepreneurs did not have enough financial capability to organize income-generating projects by themselves. Governmentsubsidized loans made it possible to increase the poor people's income and savings and raise their capability to organize themselves (Yaron, Benjamin \& Piprek, 1997). This traditional approach to rural finance directly depended on Keynesian intervention. In this approach, the main shortcomings perceived in the rural financial sector were the lack of formal financial access, lack of new technology in the agriculture sector, poor savings, and heavy dependence on informal finance, etc. State intervention was sought as a way of addressing these issues in the rural credit market. As a result, during the period 1950 to 1980 , several state-owned financial institutions were set up to solve the above problems in the rural financial sector. These institutions formulated the financial policies covering interest rate ceiling on deposits and loans, channeling loans to specific sectors, providing loan subsidies, and nationalization of private commercial banks and such.

This approach caused several qualitative issues like high default rates for loans, financial visibility of accounts, rent-seeking attitudes of borrowers, and failure to reach the core poor, etc. The end of the 1970 s saw a reorientation of the approach to rural finance. FAO organized the World Conference on Credit for Farmers in Developing Countries in 1975, which was the first step toward targeting the deficiencies of the directed and subsidized credit approach. This concept was gradually developed after the 1980 decade as the World Bank set the trend of modern thinking in the financial sector of the rural community. The traditional governmental intervention approach was criticized by the Ohio School of Economists at the Ohio State University, who then proposed a new subsidized credit approach to be adopted in the World Bank's operational policies.

As a result of new developments in rural finance approaches, lending institutions developed a new operational paradigm with the emergence of microcredit provided at lower risk and transaction cost to financial institutions. Bangladesh, Bolivia, and Indonesia proved the success of microcredit to rural communities without collateral requirements in the 1980s. Microcredit was recognized as a better outreach and cost recovery tool for lending to the poor (Rhyne, 2001). The minimalist approach was used to provide 
microfinance to the poor. This approach offered a few microfinance services to the poor. The 1990s proved to be a significant decade for microfinance related theories. MFIs now offer different microfinance services to their clients and this is known as the financial integrated approach. The theories of microfinance mainly consider the outcomes of microfinance, and so the poverty lending approach and financial integrated approach have been identified as the key approaches relating to microfinance. This paper presents the theoretical aspects relating to microfinance on poverty alleviation.

\section{RESEARCH METHODOLOGY}

The paper intends to analyze the past theoretical literature to provide a more comprehensive understanding of microfinance on poverty reduction. The research was followed by the integrative review method based on the available past literature on the theoretical analysis of microfinance. An integrative review method is a key approach that allows methodologies to review theories. Information was gathered from relevant theoretical papers, books, and other relevant documents. Collected literature was analyzed under two categories as theories address the specific issues the poor have to face when seeking access to formal financial resources and theories are based on the impact of microfinance on different sectors.

\section{RESULT AND DISCUSSION}

Widespread discussion and ever-growing attention focused on microfinance have resulted in various evolving theoretical analyses on the emergence of conceptual frameworks. The potential of microfinance as a tool of poverty alleviation has created processes and methodologies designed to provide access to financial resources to the poor for pulling themselves out of poverty through wealth creation. Hence, the perception of microfinance as a route out of poverty and a means of achieving a more equitable society has attracted the attention of policymakers and academics, paving the way for the emergence of new theories and concepts.

Microfinance-related theories can be divided into main two classes. The first group of theories addresses the specific issues the poor have to face when seeking access to formal financial resources, due to the lack of collateral. Financial institutions are also deterred by the problems of collecting actual personal information and repayment details from the poor who have a low overall 'debt capacity' (Ngimanang, 2020; Duvendack et al., 2011). One theory elaborates on this concern regarding the monitoring and screening of loans given through group lending. The second set of theories is based on the impact of microfinance on small businesses, households, and individuals. Some theories express concerns about the way the poor access the different opportunities and fail to balance the income and expenditure when engaging in microfinance activities.

\subsection{THEORIES THAT AdDRESS the SPECIFIC ISSUES RELATING tO MARKET FAILURE}

The low-income earners now have access to financial services to fulfill their different types of financial problems (Johnson, 2020; Bullock et al, 2020; Rutherford, 2000). These problems 
can be divided into three main categories as life-cycle needs, emergency needs, and investment needs. Usually the poor used to access informal financial sources to meet their basic financial needs but this solution did not fulfill all the needs of the poor. Moneylenders and pawnbrokers charge higher interest rates because of the high risk attached to repayments and collateral issues. To overcome this limitation, there must be proper financial services to meet the basic financial needs of the poor society. Even small credit facilities could enhance the small-scale business activities of the poor significantly and this would achieve much to reduce the poverty level in developing countries (Augsburg et al., 2015). However, the majority of the poor are engaged in the agricultural sector and the informal sector. The agriculture sector always saw serious drops in income as the result of seasonal changes, weather conditions, diseases, and natural disasters. Formal financial institutions are thus hesitant to fund these low-income households as asymmetric information problems make it costly for the formal sector to verify the repayment risks of the poor. A moral dilemma is the issue faced by the formal financial sector because banks are unable to monitor the borrowers' financial behaviors. This results in credit failure in the formal financial sector. The microfinance sector has tried to fill the gap between the formal financial sector and poor society by providing intermediate financial services (Chitimira, 2020; Creedy \& Hoang, 2018). The concept of group lending is used as the main instrument to overcome this barrier and enable access to financial services by the poor based on the experience of Grameen Bank in Bangladesh. MFIs providing microcredit for various purposes and clients utilize this credit not only for creating new income generation projects but also use for consumption purposes. Repayment of credit by the poor is unsecured and the MFIs are not backed up by securities.

There are several theories to address the specific problems of collateral issues relating to the poor due to their lack of repayment ability. Therefore, the poor are unable to reach the formal financial market at an affordable cost. Those theories are useful for the monitoring and screening of loans through group lending to overcome financial market failures. There are a few key theories relevant to this group as discussed below.

\subsubsection{Theory Related to Emergence of Microfinance}

Theory of market failures attributes the emergence of microfinance to the failure of financial markets (Nogueira, 2020; Brihaye et al, 2019; Srnec \& Svobodová, 2009) to include the poor in their financial services on the grounds of transaction cost and imperfect information leading to market failures. The reasons why formal banks and financial institutions did not supply credit to the poor are explained by this theory as a market failure in responding to the need for financial resources and other services. It resulted from inefficient allocation of goods and services in the market, associated with non-competition, externalities, and public goods.

$\mathrm{Xu}$ et al. (2019) and Morduch and Armendariz (2005) described what is meant by high transaction cost, information asymmetry, and market failure. When the banks or lending institutions do not have enough information on the applicant's riskiness, information asymmetry arises and so they will charge a higher interest rate to compensate for the high risk that accompanies the transactions. Information asymmetry with poor borrowers 
involves adverse selection, moral hazards, auditing cost, and enforcement. All these will drive out poor investors out of the formal financial markets indicating a market failure.

This theoretical analysis points out that microfinance lending programs have overcome most of the problems associated with market failures caused by information asymmetries by adopting innovative approaches such as group lending. According to Morduch and Armendariz (2005), microfinance has an innovative mechanism that provides dynamic incentives and collateral substitutes to reduce the cost of borrowing and ensure high repayment rates. Financial markets' inability to lend to the poor is associated with such problems as lack of physical collateral, high risk of lending and resultant high-interest rates, delay in repayment, and low profitability. The group lending system is the most commonly employed mechanism by microcredit providers to pass on financial resources to the poor (Musar, 2020; Kodongo\& Kendi, 2013). The concept of joint liability accompanied by a group lending system mitigates problems caused by the above factors.

Market failure theory points out the shortcomings of the formal financial markets in catering to the needs of the poor in the economic system and suggests that new approaches with a new dimension, new attitudes, and new outlooks be adopted as in the case of microfinance institutions that filled the gap by providing capital and other financial requirements to the needy people. In addition, these new institutions and providers were able to build up enthusiasm and hope among the poor.

\subsubsection{Concept of Joint Liability Group in Microfinance}

The concept of the Joint Liability Group is one of the successful approaches followed by the microfinance sector for reducing asymmetric information issues. Simtowe et al. (2006, p. 6) state that the Joint liability lending method is "a contract in which the provision of the private good, such as an individual's access to credit, is made conditional on the provision of the public good, such as group repayment." The microfinance sector in many developing countries used this concept when providing group lending (Reddy et al 2020). The joint liability lending method requires two or more borrowers. Microfinance institutions are able to lend to them as individuals or jointly (Simtowe et al., 2006). The concept of Joint Liability Group has provided an answer to the market failure issues of the imperfect credit market and information asymmetries of the poor (Gallenstein et al, 2020; Duvendack et al., 2011). Information asymmetry of poor borrowers involves adverse selection, moral hazards, auditing cost, and enforcement (Armendáriz de Aghion \& Morduch, 2005). Because of adverse selection, the financial sources lack information about the riskiness of their borrowers. The high-interest rate should be charged from riskier borrowers rather than safer borrowers for overcoming the risk of default. Because of incomplete information about their borrowers, higher interest rates are charged to all borrowers without reference to their risk profile. A moral hazard is a concern about the loan usage of borrowers. Borrowers should utilize it for a stated purpose such as developing the business or other entrepreneurial purposes as mentioned in the agreement they entered into to get the loan from the MFI. Borrowers may have fewer repayment problems if they are given lower loan amounts than what they expected (Ghatak \& Guinnane, 1999). Moral hazard allowed the increase in repayment ability and loan amount. This concept includes the microfinance 
institution's group lending approach by focusing on monitoring and peer pressure on repayment of the loan (Karaivanov et al 2020). As a result, the literature on theories on microfinance has aimed at developing models for explaining the joint liability groups (JLG) and their success.

The Grameen Bank of Bangladesh introduced the group-lending method by using five members from the rural agricultural area and now many MFIs practice this method when lending to the poor. The group concept can be used to some extent to reduce the repayment risk of loans. The group-based lending method is more successful than the individual lending method. Later on, this concept was introduced even to many developed countries, such as the United Kingdom, Canada, and the United States (Kumari et al, 2019; Duvendack et al., 2011).

The concept of Joint Liability Group (JLG) was used by the National Bank for Agriculture and Rural Development (NABARD), India in 2014 for providing small credits to farmers. This concept is used by many MFIs in the world nowadays. In JLGL, selected beneficiaries form several groups and the MFI provides micro-credits to those groups. A group usually consists of five to ten members living in the same area and of similar socio-economic background. The group leader can be appointed by the group, but all members are mutually responsible for every loan taken by other members. If one member is unable to repay, other members should step in and pay that amount to the microfinance institution. Non-repayment by a group member means that all group members will be denied future access to loans from the institution. In this way, all the members of the groups have to be responsible for every loan taken by members and so they tend to utilize their money properly. If any member defaults, other members will try to recover the loan installment from him and pay it back to the MFI. If any person defaults on a loan, he will be denied access to loans in the future and this understanding motivates the poor to maintain discipline and manage their loans properly. According to this lending method, group members will screen, monitor, and insist on compliance by other members of the group, thereby ensuring future loans. On the other hand, the group-lending method motivates the poor to come forward and take microcredit when they are part of a group. The low lending cost of the microfinance institution can reduce the cost of the loan they give to the groups. Further, the Group Lending Method is more effective as group members live close to each other and have social ties. Many theoretical models state that the Joint Liability Group Lending Method is very effective at screening, monitoring, and enforcing group members to service the loans dutifully, making it the most effective lending method (Karaivanov et al, 2020; Haldar et al, 2016; Stiglitz, 1990; Banerjee, 2013).

The concept of the Joint Liability method is used in many developing countries by informal financial institutions to minimize the high risk of providing finance. Samurdhi microfinance is also using this concept when providing microfinance to low-income earners all across the country. The government uses the group lending method to reduce the repayment risk and increase the utilization of the loans. Samurdhi banking society can effectively screen, monitor, and persuade the group members to repay their loans through the group concept. 


\subsection{THEORIES ON IMPACT PATHWAY OF MICROFINANCE}

The theories based on the impact of microfinance are categorized in this section. Impact pathway theories discuss the impact of microfinance on different sectors of the economy, such as income-generating activities, poor people's welfare, economic development and business, women's empowerment, etc. This section discusses market welfare theories, shortcomings of microfinance development theories, and poverty lending approaches.

\subsubsection{Theory on Shortcomings of Development Finance Strategies}

This theory attributes the rapid expansion of microfinance to the shortcomings of development strategies, especially in the area of development finance (Salami, 2020; Rewilak, 2017). It identifies two main problems associated with all post-war development finance approaches.

1. Excluding the poor from accessing financial resources.

2. Subsidizing the allocation of development finance, jeopardizing its sustainability.

Up to the 1960s, the strategies adopted for development were based on western theories, which regarded GDP growth as the main objective of development. The backwardness of the developing countries, reflected in poverty and inequality, will gradually disappear with economic advancement and modernization. Development of export-oriented industries, industrialization, and commercialization of agriculture are considered as the main features of the growth and role of development finance. It is also characterized by the building of infrastructure facilities such as transport, ports, communication, and other services (Mujeri, 2020; Aghion, \& Morduch, 2000). However, policies on development finance failed to address the most severe problem of the time, because policymakers expected that it would disappear due to the positive consequences of mainstream development projects.

After realizing that the prevalence of poverty and inequalities were the main challenges to development, there was a shift in the development policies to include poverty alleviation and reduction in disparities in the 1970s. The strategy adopted was to provide access to financial resources to the poor by establishing an institutional network with the help of donor agencies. The process included establishing development banks and long-term loan funding institutions, credit allocation for the rural agriculture sector and primary sectors, subsidization of credit, interest rate ceiling on credit for identified sectors, and establishing of numerous institutions to provide training in skills development and capacity development(Tigabu, 2020). Seibel and Parhusip (1990) described this approach as a process of supply leading finance derived from old development theories.

The shift in policies from purely growth-oriented economic strategies to inequality and poverty reduction based strategies was successful in directing public credit to the identified sectors; this was done by establishing the institutional framework to implement government plans in that direction. Yet, the outcome of these new strategies was rarely successful. It ' was identified that the reasons for failure were that these programs were not reaching the target groups, low repayment rates, and high losses as problems accompanied the new strategies. Robinson (2001) pointed out that subsidized credits went to the better-off persons rather than to the poor. The World Bank (2004) expressed its 
dissatisfaction with these kinds of programs by stating that their contribution to the agriculture sector did not produce worthy results.

This situation again paved the way for a policy shift, this time from a subsidized credit system to direct aid to the poor through micro-enterprises. The emphasis was centered on strengthening inclusive finance by bringing in micro-entrepreneurs and the poorer segment of the population, including women. Personalities such as Yunus Mohamed of Bangladesh and NGOs like the Self Employed Women's Association (SEWA) in India and Latin America entered the fray and did experiments in providing microcredit (Sievers\& Vandenberg, 2007). The World Bank, the International Labor Organization (ILO), United States Agency for International Development (USAID), and some INGOs were involved in a series of discussions during the period from 1972 to 1981. At the International Committee meeting of Donor agencies for small enterprise development held in June 1988, a large number of issues related to the microfinance sector were discussed; at the meeting, Judith Fendler and other participants used the term "minimalist" to identify the credit only approach of microfinance enterprises (Sievers\& Vandenberg, 2007). These events and subsequent developments in the field of microfinance mark a shift in policies, with attention being diverted from development financing to the "minimalist" policy of poverty alleviation through providing microcredit to the poorest of the world. This did much to overcome the deficiencies of the development finance approach.

\subsubsection{Market and Welfare Theories}

As discussed in the market failure theories, problems associated with developmental financial institutions in providing financial resources to the lower-income segment of the population, resulting in the emergence of other alternatives to reach the poor and alleviate poverty. The microfinance concept itself was an outcome of such alternative approaches and initiatives, such as the Grameen Bank of Bangladesh. This bank promoted the involvement of donors, governments, NGOs, village groups, and women into a partnership based on microfinance. The success of these operations in numerous countries and places encouraged activities and action programs on microfinance to spread worldwide as the main strategy of poverty alleviation. The approaches and methodologies employed during the initial period were mainly concerned with providing capital and other resources to the poor with the objective of poverty alleviation in developing countries. These theories were extensively employed in identifying different approaches to poverty alleviation. The initial approaches were identified as poverty lending approaches.

However, the emergence of Neo-Liberal ideologies as dominant forces in regulating the international economy brought a new dimension to the microfinance sector. Neo-Liberal economists focused their attention on the cost of subsidized microcredit systems and the institutions involved in them and their dependency on donor agencies, governments, philanthropists, and NGOs. Their focus was on the sustainability of microfinance strategies in the end and market-oriented approaches to bring benefits to both credit providers and credit recipients. These Neo-Liberal ideologies were focused on finding the way for marketoriented approaches or financial system approaches. Current discussions on microfinance strategies for poverty alleviation are centered on these two theories, specifically, the 
poverty lending approach and financial system approach (Papageorgiou et al, 2020; Khan et al, 2017; Alemu, 2008).

\subsubsection{Poverty Lending Approach}

This approach emphasizes that microfinance should be employed as a tool of poverty alleviation and its overall goal is to reduce poverty by providing the capital needs of the poor, which should lead to their empowerment (Woller et al., 1999). Poverty is the main hindrance that stalls development but the welfare approaches implemented hitherto have failed to yield the expected outcome in reducing poverty. Policymakers should not be concerned about the cost of microfinance. Microfinance will reach the targeted groups empowering them financially and physically. The governments and donors should contribute to these programs while obtaining the services of NGOs and other agencies. This approach has recognized the social mission of microfinance and kept interest rates low and below market-clearing levels (Machingambi, 2020).

The poverty lending approach emerged mostly from the poverty alleviation programs spearheaded worldwide based on experience gained through the Grameen Bank type of poverty alleviation programs. The Grameen Bank concept did not give priority to male profits; instead, sustainability was ensured by strengthening the poor to build their capacities, encouraging them to form groups and go with the group responsibilities, and by empowering the women. Supporters of the lending approach argue that poverty alleviation strategies should be centered on a multiple action program that ensures access to clean water, provides shelters for families, as well as healthcare, nutrition, and infrastructure development. Credit is a basic requirement but that alone will not ensure poverty alleviation. Therefore, an integrated strategy is needed to overcome the social and knowledge problems associated with poverty.

The idea of the cost incurred and returning the debt with a yield was not considered essential by the academics and policymakers who supported this approach. Mandatory requirements were imposed for credit recipients but the major objective was to make them familiar with savings habits. Mobilization of savings to carry out poverty alleviation programs was not intended.

The critical issue arising from the poverty lending approach is sustainability. Subsidized credit programs will not guarantee the future of these programs on the one hand and on the other, they will direct the microfinance institutions (MFIs) into a risky environment. However, there are counter-arguments that priority should be given to the poverty alleviation objectives and that the aspects of social capital and social gain should be considered rather than mere profit from the programs.

\subsubsection{Financial System Approach}

Influenced by the Neo-Liberal economic thinking, the financial system approach has also seriously considered the sustainability of microfinance strategies and MFIs. This approach emphasizes offer capital to maximize operational efficiency. This approach of microfinance is linked to the "New wave of microfinance," a concept that emerged in the 1980s. This approach has won the confidence of many international organizations and agencies. The 
Consultative Group to Assist the Poor - CGAP housed at the World Bank headquarters has prepared guidelines for implementing the financial system approach. CGAP with the help of the World Bank published a document titled "The Good Practice Guidelines for Funders of Microfinance" in 2006 and published another document as an addendum to this titled, "A Market System Approach to Financial Inclusion, Guidelines for Funders" in 2015. These events indicate the involvement of world donor agencies toward the continuation of this approach.

The principal argument based on this approach is that MFIs can perform their duties by adopting market strategies when providing microfinance and achieve sustainability rather than depend on donor agencies for funding. The responsibility of caring for the poor should not rest with the credit providers. The governments and donor agencies should take that responsibility and MFIs should undertake the task of providing credit to the economically active poor on a commercial basis. It will ensure the sustainability of MFIs and the microfinance system. The MFIs will also be able to reach a larger number of the poor.

The main advantages of this approach are full cost recovery, institutional self-sustainability, and demand-driven outreach. Since the demand for microfinance is increasing, this is the only possible strategy to meet this demand. Sustainability achieved through cost recovery of debts will solve the problems associated with future capacities, the continuation of programs, and meeting the ever-increasing demand from the poor segment of the economy.

\subsubsection{Financial Integrated Approach}

Various studies on the differing approaches to microfinance lending to the poor segment of the economy and poverty alleviation find successes and failures in both approaches. Krishnamurthy et al. (2014) concluded that the financial system's approach has been useful in helping the poor people to establish microenterprises but failed to help them in the expansion of the activity due to high-interest rates and limitation on the loan amount. Because of deficiencies in the two systems, some researchers found that an integrated approach is necessary to overcome the problems associated with both approaches and to look into the weaknesses encountered in the case of each of these approaches. Orbuch (2011) suggested that to overcome the shortcomings of these two approaches an integrated approach should be adopted (Castellano et al, 2020). One approach chooses to offer only capital to maximize operational efficiency. Another approach chooses to provide additional services that bring economic and social developments. He emphasizes the necessity to have an approach that achieves a balance between financial sustainability and social impact.

The donor agencies are more interested in adopting the financial system approach but different countries are continuing to experiment with a variety of new approaches. One such approach is the education and microfinance approach practiced in Indonesia (Hadi\& Kamaluddin, 2015). The financial system approach is intended to integrate microfinance into the mainstream financial markets. However, Grameen Bank of Bangladesh still conducts its activities by giving a prominent place to the social impact of microfinance and does not seem to be interested in implementing its programs without considering the 
other requirements of the poor (Guerin, 2020). The Grameen Bank of Bangladesh has 7.9 million borrowers and $97 \%$ of them are women. The bank's accumulated loans amount to US\$ 8.17 Billion. Its recovery rate is $98 \%$. Comparative studies on the applicability and success of the two approaches will determine the future course of microfinance and its impact on poverty alleviation in the world.

Ledgerwood (1999) presented a financial integrated approach for lending by MFIs to their clients. According to Ledgerwood, the MFIs that followed the integrated approach provide a wide range of services such as financial, social intermediation, enterprise development, and social service. MFIs decide the suitable approach based on their objectives and circumstances. However, the integrated approach has some potential issues such as differentiating between social services, controlling cost for service, financial sustainability of non-financial services, etc (Kumari, 2020). The theoretical background of the study is based on the financial integrated approach.

\section{CONCLUSION, IMPLICATIONS, LIMITATIONS AND FUTURE RESEARCH DIRECTIONS.}

This paper revealed the key theories associated with microfinance on poverty reduction. The first group of theories addresses the specific issues the poor have to face when trying to access formal financial sources due to their inability to provide any collateral. Therefore, the poor are unable to reach the formal financial market at an affordable cost. Financial institutions are also deterred by problems of collecting actual information and repayment from the poor who have low overall 'debt capacity'. There are also concerns regarding the monitoring and screening of loans made through group lending. The paper discusses several theories to address the specific problems of collateral issues relating to the poor due to their lack of repayment ability. Those theories are useful for the monitoring and screening of loans through group lending to overcome financial market failures. The research reveals several theories associated with this category as a theory related to the emergence of microfinance, the concept of joint liability group in microfinance. The second set of theories is based on the impact of microfinance on small businesses, households, and individuals and expresses concerns about the way the poor access different opportunities and about their income and expenditure smoothing ability when engaging in microfinance activities. The research finding reveals the several theories related to the impact pathway of microfinance as theory on shortcomings of development finance strategies, market and welfare theories, poverty lending approach, and financial system approach, financial integrated approach. The research finding reveals that the majority of researchers used the impact pathway theories as to the theoretical background of their researches.

The outcome of the study is directly relevant to the policies of the government and MFIs. The policymakers and regulators must essentially ensure that the program has been used effectively to alleviating poverty. The study's findings revealed that specific issues the poor have to face when trying to access formal financial sources due to their inability to provide any collateral. This theoretical review provides an understanding to develop their policies 
to overcome some issues to reach the poor into the formal financial market. The concept of Joint Liability Group has provided an answer to the market failure issues of the imperfect credit market and information asymmetries of the poor. The policymakers and regulators can utilize this concept to develop their microfinance service to the poor to increase the repayment rate. The Group lending method can be used as a successful method to increase the effectiveness of microfinance programs. Impact pathway theories provide an understanding of the impact of microfinance on the poor. Police make utilize this theoretical knowledge to analyze the impact and limitation of their programs. Finally, they will help to develop their policies and programs effectively.

This study is limited to two aspects of theories on microfinance on poverty alleviation. Both these theories do not address the new elements and new outlooks of microfinance sectors, such as social intermediation and nonfinancial service on poverty alleviation in different circumstances and different geographical boundaries, hence future research can focus on detailed analysis about the theoretical background of the new different microfinance services. The following table presents a summary of the theoretical aspects of microfinance on poverty alleviation.

\section{Table 1. Summary of the research findings}

\begin{tabular}{|c|c|c|}
\hline Category & Theories & Key features \\
\hline $\begin{array}{l}\text { Theories that } \\
\text { Address the } \\
\text { Specific } \\
\text { Issues } \\
\text { Relating to } \\
\text { Market } \\
\text { Failure }\end{array}$ & $\begin{array}{l}\text { Theory Related to } \\
\text { Emergence of } \\
\text { Microfinance } \\
\text { Concept of Joint } \\
\text { Liability Group in } \\
\text { Microfinance }\end{array}$ & $\begin{array}{l}\text { Describe what is meant by high transaction cost, information asymmetry, } \\
\text { market failure, and this theory address the problems associated with } \\
\text { market failures caused by information asymmetries } \\
\text { The concept of Joint liability group of microfinance addresses the } \\
\text { microfinance institution's group lending approach by focusing on } \\
\text { monitoring and peer pressure on repayment of the loan. It has provided } \\
\text { an answer to the market failure issues of the imperfect credit market and } \\
\text { information asymmetries of the poor }\end{array}$ \\
\hline \multirow[t]{4}{*}{$\begin{array}{l}\text { Theories on } \\
\text { Impact } \\
\text { Pathway of } \\
\text { Microfinance }\end{array}$} & $\begin{array}{l}\text { Theory on } \\
\text { Shortcomings of } \\
\text { Development } \\
\text { Finance Strategies }\end{array}$ & $\begin{array}{l}\text { This theory attributes the rapid expansion of microfinance to the } \\
\text { shortcomings of development strategies, especially in the area of } \\
\text { development finance }\end{array}$ \\
\hline & $\begin{array}{l}\text { Market and } \\
\text { Welfare Theories } \\
\text { Poverty Lending } \\
\text { Approach }\end{array}$ & $\begin{array}{l}\text { The theory address providing capital and other resources to the poor with } \\
\text { the objective of poverty alleviation in developing countries. } \\
\text { This approach emphasizes that microfinance should be employed as a } \\
\text { tool of poverty alleviation and its overall goal is to reduce poverty by } \\
\text { providing the capital needs of the poor, which should lead to their } \\
\text { empowerment }\end{array}$ \\
\hline & $\begin{array}{l}\text { Financial System } \\
\text { Approach }\end{array}$ & $\begin{array}{l}\text { This approach describes offer capital with the intention of maximizing } \\
\text { operational efficiency. The principal argument based on this approach is } \\
\text { that MFIs can perform their duties by adopting market strategies when } \\
\text { providing microfinance and achieve sustainability rather than depend on } \\
\text { donor agencies for funding }\end{array}$ \\
\hline & $\begin{array}{l}\text { Financial } \\
\text { Integrated } \\
\text { Approach }\end{array}$ & $\begin{array}{l}\text { This approach emphasizes a wide range of services such as financial, social } \\
\text { intermediation, enterprise development, and social service. This } \\
\text { approaches introduced to overcome the weaknesses encountered in the } \\
\text { financial system approach }\end{array}$ \\
\hline
\end{tabular}

Source: Author developed, 2020 


\section{References}

Alemu, K. T. (2008). Microfinance as a Strategy for Poverty Reduction. The Hague Netherlands.

Augsburg, B., De Haas, R., Harmgart, H., \& Meghir, C. (2015). The impacts of microcredit: Evidence from Bosnia and Herzegovina. American Economic Journal: Applied Economics, 7(1), 183-203.

Banerjee, A. V. (2013). Microcredit under the microscope: what have we learned in the past two decades, and what do we need to know?. Annu. Rev. Econ., 5(1), 487-519.

Brihaye, T., Pril, J. D., Labie, M., \& Périlleux, A. (2019). Positive versus negative incentives for loan repayment in microfinance: A game theory approach. Review of Development Economics, 23(2), 577-597.

Bullock, H. E., Toolis, E. E., Sencion, B., \& Cadenas, M. T. (2020). The high price of economic marginalization: Low-income Latinas' experiences with mainstream banking and alternative financial services. Peace and Conflict: Journal of Peace Psychology, 26(2), 136.

Castellano, R., Cerqueti, R., \& Rotundo, G. (2020). Exploring the financial risk of a temperature index: A fractional integrated approach. Annals of Operations Research, 284(1), 225-242.

Chitimira, H. (2020). Historical Aspects of the Statutory Regulation of Financial Inclusion for the Poor and Low-Income Earners in South Africa. Acta Universitatis Danubius. Economica, 16(5).

Creedy, J., \& Hoang, H. (2018). Microfinance and joint liability lending. In Research Handbook of Finance and Sustainability. Edward Elgar Publishing.

de Aghion, B. A., \& Morduch, J. (2000). Microfinance beyond group lending. Economics of transition, 8(2), 401-420.

Duvendack, M., Palmer-Jones, R., Copestake, J. G., Hooper, L., Loke, Y., \& Rao, N. (2011). What is the evidence of the impact of microfinance on the well-being of poor people?

Gallenstein, R. A., Flatnes, J. E., \& Sam, A. G. (2020). The Role of Social Capital in Risk-Taking Decisions under Joint Liability Lending. The Journal of Development Studies, 1-13.

Ghatak, M., \& Guinnane, T. W. (1999). The economics of lending with joint liability: theory and practice. Journal of development economics, 60(1), 195-228.

Guerin, I. (2020). Microfinance Challenges: Empowerment or Disempowerment of the poor? Institut français de Pondichéry.

Hadi, N. A., \& Kamaluddin, A. (2015). Social collateral, repayment rates, and the creation of capital among the clients of microfinance. Procedia Economics and Finance, 37(2), 823-828.

Haldar, A., \& Stiglitz, J. E. (2016). Group lending, joint liability, and social capital: Insights from the Indian microfinance crisis. Politics \& Society, 44(4), 459-497. 
Johnson, R. W. (2020). Financial Challenges at Older Ages and the Implications for Housing Options. Generations, 2020.

Johnson, S., \& Rogaly, B. (1997). Microfinance and poverty reduction. Oxfam.

Karaivanov, A., Xing, X., \& Xue, Y. (2020). Bogus joint liability groups in microfinance. European Economic Review, 122, 103353.

Khan, W., Shaorong, S., \& Ullah, I. (2017). Doing business with the poor: the rules and impact of the microfinance institutions. Economic research-Ekonomska istraživanja, 30(1), 951-963.

Kodongo, O., \& Kendi, L. G. (2013). Individual lending versus group lending: An evaluation with Kenya's microfinance data. Review of Development Finance, 3(2), 99-108.

Krishnamurthy, S., Joseph, S., \& Bharathi, V. (2014). Creating environment friendly projects in rural India-A synergy framework for sustainable renewable energy. International Journal of Applied Engineering Research, ISSN, 0973-4562.

Kumari, J. P.(2020) The role of products of Microfinance for reducing the Poverty of the Borrowers: Exploratory Factor Analysis, International Journal of Management Excellence,15(3).

Kumari, J. P., Azam, S. F., \& Khalidah, S. (2019). The Effect of Microfinance Services on Poverty Reduction: Analysis of Empirical Evidence in Sri Lankan Perspectives. European Journal of Economic and Financial Research, 3(5).

Kumari, J. P., Azam, S. F., \& Yusoff, S. K. M. (2019). DOES GENDER DIFFERENCES PLAY A MODERATING ROLE IN THE RELATIONSHIP BETWEEN MICROFINANCE SERVICES AND SMALL-SCALE BUSINESS PERFORMANCE IN SRI LANKA?. European Journal of Social Sciences Studies, 4(5).

Ledgerwood, J. (1999). Sustainable banking with the poor microfinance handbook.

Machingambi, J. (2020). THE IMPACT OF MICROFINANCE ON THE SUSTAINABILITY OF 'POOR'CLIENTS: A CONCEPTUAL REVIEW. Journal of ENTREPRENEURIAL INNOVATIONS, 7(1), 50-50.

Morduch, J., \& Armendariz, B. (2005). The economics of microfinance. mit Press.

Mujeri, M. K., \& Mujeri, N. (2020). Financial-Real Sector Nexus. in Bangladesh at Fifty (pp. 493-534). Palgrave Macmillan, Cham.

Musari, K., \& Azid, T. (2020). Islamic Nano-Finance for the Very Poor by Women: Hopes for Addressing the Islamic Microfinance Gap. World Scientific Book Chapters, 265286.

Ngimanang, A. (2O20). MICROFINANCE SERVICES AND THE GROWTH OF SMALL AND MEDIUM SIZE ENTERPRISES: EVIDENCE FROM THE COMMUNITY CREDIT COMPANY IN THE DOUALA MUNICIPALITY, CAMEROON. International Journal of Business Strategies, 5(1), 27-50. 
Nogueira, S. A. G. (2020). Microfinance-A Theoretical and Empirical Assessment (Doctoral dissertation, Instituto Politécnico do Porto. Escola Superior de Tecnologia e Gestão).

Orbuch, E. (2011). Towards an Integrated Approach to Microfinance. A case for the Integration of.

Papageorgiou, K., Singh, P. K., Papageorgiou, E. I., Chudasama, H., Bochtis, D., \& Stamoulis, G. (2020). Participatory modelling for poverty alleviation using fuzzy cognitive maps and OWA learning aggregation. Plos one, 15(6), e0233984.

Reddy, A., Gupta, S. D., \& Festona, B. N. (2020). Joint Liability Group (JLG) activities of "Kudumbashree" Initiatives: A case study based on rural areas of Kerala, India. CLIO An Annual Interdisciplinary Journal of History, 6(6), 54-62.

Rewilak, J. (2017). The role of financial development in poverty reduction. Review of development finance, 7(2), 169-176.

Rhyne, E. (2001). Mainstreaming microfinance: How lending to the poor began, grew, and came of age in Bolivia (No. 332.1 R4.). Bloomfield, CT: Kumarian Press.

Robinson, M. S. (2001). The microfinance revolution: Sustainable finance for the poor. The World Bank.

Rutherford, S. (2000). The poor and their money. New Delhi: Oxford University Press.

SALAMI, L. A., ADEBOSIN, W. G., SAULA, D. T., ADEWALE, T. A., \& GEORGE, E. O. MICROFINANCING AND RURAL ECONOMIC PERFORMANCE IN NIGERIA: A REVIEW OF LITERATURE. HALLMARK UNIVERSITY, 192.

Seibel, H. D., \& Parhusip, U. (1990). Financial Innovations for microenterprises-linking formal and informal institutions. 2003) Microfinance: Evolution, Achievement and Challenges. ITDG Publishing, London.

Sievers, M., \& Vandenberg, P. (2007). Synergies through linkages: Who benefits from linking micro-finance and business development services? World development, 35(8), 1341-1358.

Simtowe, F., \& Zeller, M. (2006). The Impact of Access to Credit on the Adoption of hybrid maize in Malawi: An Empirical test of an Agricultural Household Model under credit market failure.

Srnec, K., \& Svobodová, E. (2009). Microfinance in less developed countries: history, progress, present-charity or business? Agricultural Economics, 55(10), 467-474.

Stiglitz, J. E. (1990). Peer monitoring and credit markets. The world bank economic review, $4(3), 351-366$.

Tigabu, D. G., \& Gebeyehu, M. F. (2020). Enhancement of Employment and Income Opportunities for Rural Youth in Ethiopia: A Review of Four Large Youth Employment Initiatives (p. 35). FARA Research Report 5 (4). 
Woller, G. M., Dunford, C., \& Woodworth, W. (1999). Where to microfinance. International Journal of Economic Development, 7(1), 29-64.

World Bank Staff. (2004). Education in Rwanda: Rebalancing resources to accelerate postconflict development and poverty reduction. World Bank Publications.

World Bank, (2019). Poverty, retrieved from https:// www. Worldbank.org/en/topic/poverty/overview

Yaron, J., Benjamin, M. P., \& Piprek, G. L. (1997). Rural finance: Issues, design, and best practices (Vol. 14). Washington, DC: World Bank. 